\title{
THE CASE FOR A SPECIAL RAILROAD REORGANIZATION COURT
}

\author{
Cassius M. Cina*
}

As this article is being written, it seems probable that no legislation will be enacted at this session of Congress with respect to the largest of America's ailing corporation-type industries-the railroads. In that event, the particular bills before the present Congress, ${ }^{1}$ and the reasons for their failure, are less important than the unanswered question of what, in a.democratic government such as ours, can and should be done to help the railroads. A well-maintained and economically sound transportation system is essential not only for our economic and social well-being but also for purposes of national defense.

Although railroad earnings started to improve even before the outbreak of the European War, it is delusive to suppose that the improvement which has occurred "will in itself 'solve the transportation problem' or render constructive attempts to deal with it unnecessary." 2 The troubles of the railroads would appear duc to a variety of causes ${ }^{3}$-among others: loss of traffic to trucks, airplanes and waterways, the slowness of the managements to appreciate that they no longer have a monopoly of transportation and to adjust their service and rates accordingly, incredibly complex capital structures which interfere with the obtaining of credit for the modernization of their equipment and facilities for effective competition, the weakening of some of the stronger systems by ill-advised purchases of stock of other railroads in the boom days, higher taxes and costs of operation, loss of export markets, the decentralization of big business which has progressed with increasing momentum during the last decade, and the fundamental fact that with a nation-wide system of highways

- A.B., I918, LL.B., I921, Yale University. Member of the Kentucky and New York Bars. Member of the legal staff of the Reconstruction Finance Corporation, in charge of legal section on Railroads since 1932, with present title of Assistant General Counsel of the Corporation. Author of several books, including: Puslic Utmuty Regriation-A Crucul. Problen in Constitutional Government (Holt * Co., 1932); What Shall We Do about the Raizronds? (Ransdell, Inc, 1939).

This article is written entirely in the author's private capacity and not in his official one.

${ }^{2}$ For legislation pending at the beginning of the 3d Session of the 76th Congress, see Dembitz, Progress and Delay in Railroad Reorganizations since 1933, supra p. 394, n. 13.

ICC, 53 d AN.. REP., (1939) 5.

- See Fufteen Percent Case, 1937-1938 (Ex Parte No. 123), 226 I. C. C. 41, and particularly Commissioner Eastman concurring, at p. 144; REPORT OP EMERGENCY BONRD APPONNTED SEPT. 27, 1938. UNDer 5 Io of RatLway LABor ACt; ICC, 52d ANN. Rep. (1938) I-25; ICC, 53d ANN. Rep. (1939) 5-16; Hearing before the Special Subcommittee on Bankruptcy and Reorganization of the House Committee on the 7udiciary, on S. 1869, 76th Cong., Ist Sess. (1939) Ser. No. 11, Pt. 2, App. B (hereinafter cited as "House Hearings"). 
and improved waterways the country does not need as many railroad lines today as it did a generation ago.

The question of what, short of government ownership, the government should do in the circumstances, was brought to the attention of the $75^{\text {th }}$ Congress through the medium of the President's White House Conference on Transportation in March, 1938, and his subsequent Special Message of April, ז938, entitled "Immediate Relief for the Railroads," with which he transmitted the report of a special committee of three members of the Interstate Commerce Commission, Commissioners Eastman, Mahaffie and Splawn, together with the various comments and suggestions thereon of the other conferees."

Those familiar with the facts realize that the so-called railroad problem cannot be satisfactorily met solely by the improvement of reorganization procedure. With the railroads no longer enjoying the monopoly of transportation they once had, it would seem in the public interest that competition between railroads be reduced, so they may compete more effectively with newer rivals. ${ }^{5}$ Substantial economies could doubtless be realized through consolidations, if means can be found to meet the objections of labor, concerned with the prospective loss of jobs. The position of labor on this score is perhaps less serious than the division of opinion as to the wisdom of consolidations prevalent among the railroad executives, some of whom are motivated by considerations no less personal than those of labor."

If, however, it be true thar the salvation of the railroads is to permit them to consolidate so they can compete more effectively with trucks, airlines, etc., then a solution of the railroad problem must await the reorganization of the $30 \%$ of the mileage of the country which is now involved in court proceedings, as well as the reorganization of other mileage which, for various reasons, is having difficulty meeting its fixed charges. Consolidation by a road in reorganization with another not in the same system, simultaneously with their reorganization under Section 77, presents such a multiplicity of problems as not ordinarily to be feasible. ${ }^{7}$

There can be no dispute, moreover, as to the need of getting the roads that are now involved in court proceedings reorganized. A peculiar characteristic of the railroad industry, as contrasted with manufacturing-type industries, has always been

${ }^{4}$ H. R. Doc. No. 583, 75th Cong., 3d Sess. (2938).

s See Clay, What Shall We Do about the Railroads? (Ransdell, Inc. 1939): The original form of this little book was a memorandum, circulated privately, upon request, among the members of the U. S. Chamber of Commerce's Conference on Transportation, held in the Fall of 1938, and furnished later in the same year to the Railway-Executive Labor Commitree of Six.

- See popular discussion by Craven, Railroads Under Pressure (Dec. 1938) 162 ATr. Montrily 767.

'See ICC report and order, Jan. 19, 1939, Chicago \& N. W. R. R. and Chicago, Milwaukee, St. P. \& P. R. R. Reorgs., Fin. Doc. Nos. 10881, 10882, refusing to reopen bearings to consider a new plan providing for the consolidation of those systems. The Commission said (mimeo. rep. at 5-6): "The difficulties of preparing a plan for a consolidated reorganization would be multiplied, as would also the questions of law and fact sure to arise. The number of persons, interests and communities that would be affected by consolidation makes it certain that it could be approved, if at all, only after very extended hearings. Where so many commurities are affected, years would be taken to abandon lines and settle the other quesions that are necessarily involved." 
the large capital investment involved and the high level of fixed charges. ${ }^{8}$ And connected with this is a striking aspect of the railroad problem-the large number of companies now involved in reorganization in bankruptcy or in equity receivership.?

From the standpoint of its effect upon general economic activity, a huge railroad system in the process of reorganization is like a man in a hospital on a diet. It is denied financing itself as a healthy road can, since trustees' and receivers' certifcates can only be issued for limited purposes. Likewise, though it may spend more on health-cures and doctors' bills than a road that is struggling to meet its bond interest and keep out of the hospital, it has not the freedom, possessed by other companies, which are not in the hospital, to adapt itself to competition.

The prospective adjournment of Congress without effective action looking toward a solution of the railroad problem, the unlikelihood of any substantial change for the better in the basic conditions confronting the railroads; and the failure of Section 77 of the Bankruptcy Act $^{10}$ to provide a fully satisfactory reorganization procedure $^{11}$-all increase the need for the improvement of existing railroad reorganization procedure. The experience of the past seven years and the failure to get even a single system reorganized and out of court, calls for more direct thinking about the future of our transportation system. It calls for streamlining of our bankruptcy procedure, so that the needs of the future, whatever they may be, can be met, and met effectively. The problem is of national importance, calling for national action in the creation of a special court charged with the duty of devoting its full time to the task of getting insolvent roads that are now being run by the courts back into private hands.

In the space allowed to present the need for a special railroad reorganization court, we shall briefly review the background of the proposal, the advantages of such a tribunal as contrasted with the obvious defects of Section 77 in its existing form, and the reasons why the creation of such a court would be a step in the right direction.

\section{Background of the Proposal for a Special Court to Handle Railroad Reorgantzations}

The suggestion that a special court be created to consist of specially qualified judges with jurisdiction in railroad reorganization cases, antedates the enactment of Section 77 in its original form. Under date of January 3r, 1933, the legislative committee of the Interstate Commerce Commission, in a letter to Senator Daniel $\mathbf{O}$. Hastings, replying to his request for the Commission's views on two bills which in

- See hadley, Ralload Transportation (1885) c.lli.

- See Dembitz, supra note $\mathrm{I}$, at 394-396.

${ }^{10} 49$ STAT. 917 (1933), 25 amended, 11 U. S. C. A. $\$ 205$.

27 Since $577^{\prime}$ 's enactment, on March 3, 1933, the reorganization of not a single Class I railroad has been completed thereunder. (Class I railroads are those having annual operating revenues above $\$ 1,000,000$.) Though on Jan. 10, 1940, and March 26, 1940, plans of reorganization were confirmed for, respectively, the Chicago and Eastern Illinois and the Chicago Great Western-roads having $c x$ tremely simple capital structures-nevertheless, as of the present date (June 1, 1940), no applieation had been made in either case to the I. C. C. for its approval of the R. F. C. loans, in each case one of the necessary steps to the successful effectuation of the reorganization plans. 
a somewhat modified form later became Section 77 , indicated that the proposed bills did not go far enough. This Committee stated in part: ${ }^{12}$

A thorough-going reform of reorganization procedure in the public interest would go to this root of the matter, and would entrust the working out of an equitable and effective reorganization from the beginning to some well-informed, well-equipped, and disinterested branch of the public service, just as has been done to some considerable extent in the case of banks and insurance companies. This could be done through a special court created for this single purpose, or through a special department of the Commission likewise created for the purpose. We have no doubt that capable and experienced men could be employed, in part permanently and in part temporarily, by such a court or department who would be able to perform adequately and efficiently, and at much less cost, the work which would be performed under either the Senate or the House bill by the trustees, seorganization managers, and their counsel. [Italics added.]

The legislation which you are considering is, in short, hybrid legislation. It recognizes the evils in the present system of reorganizing railroads, but instead of dealing with these evils at the source, it attempts to correct them by means of coordinate regulation. The Commission is to act as a corrective of possible errors of a preoccupied and perhaps inexperienced court, and together they are to watch and supervise, with the aid of the trustees, the process of formulating and procuring agreement to a plan of reorganization.

We should prefer to see an attempt made to deal more fundamentally with this matter, but we realize that the time is short, if anything is to be done at the present session, and that the need for action is urgent. We realize, also, that legislation of the more thorough-going character which we suggest would involve so radical a change in accustomed procedure that it would meet with the resistance which all such changes encounter, and would probably entail long discussion.

That the establishment of a special railroad reorganization court be considered was again recommended by the Interstate Commerce Commission itself early in 1938.13 At the White House Conference on Transportation in March, 1938, such a tribunal was recommended by at least two of the conferees, Mr. Henry Bruere, President of the Bowery Savings Bank of New York, ${ }^{14}$ and the then Chairman of the Securities and Exchange Commission, now Mr. Justice Douglas. ${ }^{18}$ Later in the same year it was again recommended by the Railway Executive-Labor Committee of Six. ${ }^{16}$ At hearings before committees of the Senate ${ }^{17}$ and the House, ${ }^{18}$ the proposed court was endorsed by Mr. Jesse H. Jones, then Chairman of the Reconstruetion Finance Corporation and now the Federal Loan Administrator. It is reported that Sunator Wheeler, co-sponsor with Senator Truman of railroad legislation in the Senate, had other important administration support for the proposal.

25 Letter reprinted in Hearings before Senafe Commitsee on Interstate Commeree on S. 1869, 76th Cong., 1st Ses. (1939) 288, 297-298 (hereinafter cited as "Senate Hearings").

19 Under date of March 24, 1938, three members of the I. C. C., in a report concurred in by the full Commission, one member absent, reported to the President as follows: "Possibly the establishment of one court to have charge of railroad reorganizations may be desirable." The President communizated this suggestion to the Congress in the following words: ". . . they suggest the establishment of a single court in charge of reorganizations." H. R. Doc. No. 583, 75th Cong., 3d Sess. (1938) 1, 33. Sce also House Ilearings, Pt. 3 , p. I4.

14 H. R. Doc. No. 583 , supre note 13 , at 64. 16 Id. at 58-59.

10 Report of President's Comnotiee to Submit Recommendations upon General Tinanspontation Siruation (Dec. 1938) 25-28.

${ }^{17}$ Senate Hearings, 313-323. $\quad$ "House Hearings, Pt. 1, p. 921. 


\section{Advantages of Establishing a Special Trubunal}

In the 76 th Congress, provisions for the establishment of a special railroad reorganization court were contained in separate bills introduced in the Senate ${ }^{10}$ and House. ${ }^{20}$ Limitations of space prevent a detailed analysis of these bills, or of the House bill ${ }^{21}$ introduced late in the present session as a substitute for the bill passed by the Senate in the first session. Criticism of particular provisions contained in these bills-such as the so-called capitalization standards contained in the Senate bill $^{22}$-is of questionable value unless such criticism is made for the purpose of developing a satisfactory railroad reorganization statute. Since, on the contrary; much of the testimony given before the committees of Congress would appear to have been aimed more towards the obstruction of any affirmative action, rather than towards corstructive assistance in improving the existing statute, it becomes important-if the case for a special railroad reorganization court is to be stated fairly-to outline briefly its advantages.

(1) The creation of a special railroad reorganization court composed of specially qualified judges will relieve the federal district courts of a class of cases which impose a heavy burden upon their time and attention, and should result in the consummation. of sounder reorganization plans. The federal district courts are courts of general federal jurisdiction. In them, a railroad reorganization case may be preceded or followed by one in tort or contract; an income-tax fraud case, by one involving real estate titles. The average federal district judge is necessarily handicapped in handling a matter involving such specialized problems as a railroad reorganization. ${ }^{28}$

Serious, from the standpoint of the national economy as a whole, has been the failure of the district courts (due, undoubtedly, in most cases, to the other demands upon their time and to lack of previous experience in similar cases) to inquire into and consider the financial soundness and feasibility of plans that are presented, as well as their fairness and equity. Many of the roads now in the courts are repeaters -that is, in the past, reorganization has succeeded reorganization with the regularity of a planetary movement. Undoubtedly, some of these roads, because they operate either under intense competition or where traffic is thin, or for both reasons, are naturally weaker than their stronger rivals. Too often, however, subsequent insolvency is traceable to a preceding reorganization from which the road emerged without an adequate medium for new financing or with a capitalization larger than it was able

${ }^{10}$ S. 1869, 76th Cong, rst Sess. (1939).

${ }^{10}$ H. R. 2531, 76th Cong., Ist Sess. (1939) tit. III.

${ }^{21}$ H. R. 9447, 76th Cong., 3d Sess. (1940).

is $\$ 77(\mathrm{u})$, as amended by S. 1869 .

${ }^{28}$ Evideace of this is the tendency of the federal district courts which have jurisdiction of such cases to refer consideration of plans to a special master. Cf. Order of Judge Luther B. Way, Oct. 2, 1939, Seaboard Air Line Reorg., Ct. Rec., pp. 15358-9, stating that the questions arising therein "would demand the devotion of an amount of time to such detail not available to the Court because of its numerous other problems and duties, administrative and judicial."

Even on questions of administration arising prior to consideration of a plan, it has been the practice in some of the district courts, e.g., in the Erie, Missouri Pacific, Frisco, and Rock Island cases under $87 \%$, to refer such questions to a special master. 
to support ${ }^{24}$ or even larger, in certain instances, than before it became involved in court proceedings. ${ }^{23}$

(2) A special court is designed to promote a closer brigading ${ }^{20}$ of the administrative finding with the judicial process than is permitted by the present bankruptcy statute. This is most desirable, especially in instances where value becomes the test of fairness. With the accent which Congress as well as the Supreme Court ${ }^{27}$ has placed upon the fairness of the plans of reorganization, to the disregard as a practical matter of a sale at an upset price, the central problem where a plan is contested is value-that is, the value of the property as a whole for purposes of reorganization, the value of particular issues of securities dealt with by the plan; etc. "Value," needless to say, "is a word of many meanings."

In the form originally enacted, Section 77 contained no valuation standards. It likewise was defective in that it was impossible within the language of the statute, to obviate submission of the plan to existing classes of stock for their acceptance or rejection without a previous finding by the court that the debtor was insolvent. ${ }^{20}$ Although the authors of the 1935 revision of Section 77 sought to remedy these matters by providing that "if it shall be necessary to determine the value of any property for any purpose under this Section" the Interstate Commerce Commission shall determine such value, ${ }^{30}$ the conclusiveness of such a finding has not yet, five years after the passage of the 1935 Act, been passed upon by the Supreme Court. It is now at issue in the Western Pacific reorganization, ${ }^{81}$ the first case involving a Class I railroad in which the plan approved by the Commission has met with opposition from the debtor corporation.

\footnotetext{
26 As in the case of the 1927 reorganization of Chicago, M., St. P. \& P. R. R. For details of this rcorganization, sec Lowenthal, The Investor Pay (1933).

${ }^{96}$ See statistical analysis of 31 reorganizations of Class I railways, 1914-1933, D. Philip Locklin, ICC Bureau of Statisties (not considered or adopted by ICC). This study discloses that in these 31 equity cases the aggregate capitalization was reduced less than $10 \%$. Eight came out with larger capitalizations than before reorganization. The net reduction for the 31 was less than the reduction in investment in road and equipment plus improvements on leased railway property. Only two of the eight cases in which the capitalization was increased occurred before the Transportation Act, I920.

${ }^{28}$ See Mr. Justice Frankfurter in Palmer v. Massachusetts, 308 U. S. 79, 87 (1939): "The judicial process in banknuptcy proceedings under $\mathbf{5 7 7}$ is, as it were, brigaded with the administrative process of the Commission." (Italies added.)

${ }^{17}$ See $577(e)$, requiring the judge to be satisfied that the plan "is fair and equitable"; 577 (d) requiring the I. C. C. to approve 2 plan "that will in is opinion meet with the requirements of subsections ... (e)." See also National Surety Co. v. Coriell, 289 U. S. 426 (1933); First Nat. Bank v. Flershem, 290 U. S. 504 (1934); Taylor v. Standard Gas \& Elec. Co., 306 U. S. 307 (1939); Case v. Los Angeles Lumber Products Co., 308 U. S. 106 (1939).

${ }^{2 x}$ Mr. Justice Brandeis, dissenting, in Southwestern Bell Tel. Co. v. Public Service Com'n, 262 U. S. 276, 310 (1923).

"Apparently, insolvency in the bankruptcy sense. See Bankruptcy Act, 5I(15): "A person shall be deemed insolvent ... . whenever the aggregate of his property, . . . shall not, at a fair valuotion, be sufficient in amount to pay his debts." (Italics added.)

${ }^{80} \mathrm{~S}_{77}(\mathrm{e})$ last par.

82 Although a hearing in this case on objections to the I. C. C.'s plan was held by the District Court Jan. 22, 1940, no decision is likely until after a hearing, which has been postponed from June 3 to August 5, 1940, on allowances to be made to parties. The I. C. C.'s order fixing maximum limits thercon was made May 27, 1940.
} 
(3) Without such a closer brigading, the completion under the present statute of plans, even though relatively far advanced, is imperilled. Inclusion in the present act, ${ }^{32}$ as in the Transportation Act, $1920,{ }^{33}$ of a mandate to the Interstate Commerce Commission to give effect to certain elements of value, involves a risk that if, as in the O'Fallon case, ${ }^{34}$ the courts determine that the Commission has applied those standards insorrectly, much of its work in other pending reorganizations may have to be done over, with the effect of postponing indefinitely the completion of plans in the latter cases, though these may be relatively far advanced.

(4) Dual litigation, for which the present statute affords too many opportunities, would tend to be minimized, were a special court created. The Interstate Commerce Commission, experienced in administering the LaFollette Valuation Act of 1913 and with its specialized knowledge of railroad matters, has been realistic, in the plans which it has approved, on such matters as total capitalization and the amount of fixed charges which reasonably might be supported, drastically reducing these where excessive. ${ }^{35}$ The existing act places upon the Commission an extremely difficult burden in requiring it, before certifying the plan to the court, to decide controverted issues of law which only a court can determine with finality. In so providing Congress has saddled the Commission with a function beyond its capacity as an administrative body, for, no matter how financially sound may be the plan worked out by the Commission, it is without power to make the plan binding. Should the courts determine that an error of law has been committed by the Commission, the whole plan can be upset. ${ }^{36}$ Throughout the time hearings on the plans are being held before the Commission and until it certifies a plan to the court, the Commission and the court are thus placed in a dilemma. Since Section 77 requires the court, if it disapproves the plan, to refer the plan back to the Commission for further proceedings, ${ }^{37}$ a continued shuttling of the case between court and Commission is theoretically possible.

${ }^{23} 377$ (c) last par.: "If it sball be necessary to determine the value of any property for any purpose under this section, the Commission shall determine such value and certify the same to the court in its report on the plan. The value of any property used in railroad operation shall be determined on a basis which will give due consideration to the carning power of the property, past, present, and prospective, and all other relevant facts. In determining such value only such effect shall be given to the present cost of reproduction new and less depreciation and original cost of the property, and the actual investment therein, as may be required under the law of the land, in light of its earning power and all other relevant facts."

It is to be noted that noder the above provision it is not necessary to have a determination of value in every case.

22 5 I5a(4), 49 U. S. C. \$25a, directing that in determining values of railway property for purposes of recapture the Commission "shall give due consideration to all the elements of value recognized by the law of the land for rate-making purposes, and shall give to the property investment account of the carriers only that consideration which under such law it is entilled to in establishing values for rate-making purposes."

"St. Louis \& O'Fallon Ry. v. U. S., 279 U. S. 46 r (1929).

st Statement of Mr. F. W. Walker, House Hearings, Pt. 1, p. 66o, Ex. No. 4.

${ }^{30}$ See Commissioner Splawn, concurring, in Chicago \& N. W. R. R. Reorg., Fin. Doc. No. 10881 (Dec. 12, 1939) mimeo. rep. at 160: "If 2 stockholder could convince the court of the existence of an equity to which he has just claim, the court would immediately set aside any order of this Commission purporting to interfere with such an equity."

$\$ 77(e)$ par. 2. 
More curious to date have been the delays in settling mixed questions of law and fact while one or more plans are still before the Commission. With jurisdiction split between the Commission and the court, and the parties free to litigate the same questions or different phases of related problems contemporaneously before both, no satisfactory technique for meeting this problem has been evolved, as is evidenced in the Rock Island and New Haven reorganizations, ${ }^{38}$ in which the volume of litigation has been equally staggering. ${ }^{30}$

(5) Expedition of proceedings, one of the primary purposes of Section 77, would be promoted by the creation of a special court and the adjudication of unsettled issues of law. Section 77 had as a primary purpose the reduction of the delays and expense which had characterized previous railroad reorganizations. ${ }^{40}$ The 1935 revision, while it introduced some improvements, is procedurally more complex than the original

\footnotetext{
s" $\mathrm{Cf}$. the following extracts from colloquy between counsel and court in the Rock Island case, in a hearing before Judge Wilkerson on April II, 1940, on petition of Choctaw Committee for payment of interese. "Mr. Vernon: We filed 2 plan. We spent 2 lot of time, we had hoped when we'agreed with the Commission back in March, 1938, we agreed we would file a plan, and at that time it was our hope that we would be able to get an agreed plan. We have just about as many rules as we have Judges as to what the Court should really do in these eases before the plan comes before the Court. Evidently the Congress intended that about all the Court should do was to try and preserve the status and conserve the property until the Commission had worked out a plan, and this statute does not work in very well with a proceeding which has been going on over a period of seven years . . " (Transcript, p. 153). "The Court: I presume that is true. A Judge hardly knows what to do with these questions that come up, whether to take them and decide them or just simply do nothing about it until the plan is submitted ..." (id., p. 154). "The Court: It is quite a puzzle in those cases for a Judge to know just what he has to do before the plan comes..." (ibid.).

On the other hand, Judge Hincks, on petition for Order No. 369 in the New Haven case, stated: ". . . I take into account the following facts: that the expense was occasioned by the successful defense of a claim of prior lien on system property included within the scope of the contemplated reorganization; that an adjudication of the resulting controversy was a prerequisite to an accurate ond intelligent appraisal of the treatment accorded in our proposed plan to the property affected. . . (Italics added.) Ct. Rec. p. 6472. See also his memorandum decision declaring $\$ 77$ constitutional on petition for declaratory judgment. In re Scofield, Ct. Rec. p. 102r.

"Some indication of the amount of litigation in each of these proceedings is shown by the following contested matters on which appeals have been taken. The list does not purport to be complete, and lower court decisions are omitted.
}

Appeals in the Rock Island Reorganization: Continental IIl. Nat. Bk. \& Trust Co. v. Chicago, R. 1. \& P. Ry., 294 U. S. 648 (1935); Lowden v. Northwestern Nat. Bk., 298 U. S. 160 (1936); In re Chicago, R. I. \& P. Ry., 90 F. (2d) 795 (C. C. A. 7th, 1937); In re Chicago, R. I. \& P. Ry., Wise V. Chieago, R. I. \& P. Ry., go F. (2d) 312 (C. C. A. 7th, 1937), cert. denied, sub. nom. Bankers Trust Co. v. Wise, 302 U. S. 717 (1937); U. S. v. Lowden, 308 U. S. 225 (I939); In re Chicago, R. I. \& P. Ry., Beebe v. Cheston, Chase Nat. Bk. v. Cheston, xo8 F. (2d) 410 (C. C. A. 7th, 1939); In re Chicago, R. I. \& P. Ry., Blaine v. Cheston, IIo F. (2d) 395 (C. C. A. 7th, 1940).

Appeals in the New Haven Reorganization: In re New York, N. H. \& H. R. R., C. C. A. 2d, Dec. 30, 1936; Connecticut Ry. \& Ltg. Co. v. Palmer, 305 U. S. 493 (1939); Connecticut Ry. \& Ltg. Co. v. Palmer, 109 F. (2d) 568 (C. C. A. 2d, 1940); Old Colony R. R. v. New York, N. H. \& H. R. R., 98 F. (2d) 670 (C. C. A. 2d, 1938), cert. granted in part, sub. nom., Palmer v. Palmer, 305 U. S. 578 (1939), denied in part, id. 660; New York Trust Co. v. Palmer, ror F. (2d) I (C. C. A. 2d, 1939); Merchants Nat. Bk. v. New York, N. H. \& H. R. R., 102 F. (2d) 923 (C. C. A. 2d, 1939); Bankers Trust Co. v. New York, N. H. \& H. R. R., 104 F. (2d) I018 (C. C. A. 2d, 1939); Palmer v. Palmer, 104 F. (2d) 161 (C. C. A. 2d, 1939), cert. denied, 308 U. S. 591 (1939); Palmer v. Massachusetts, 308 U. S. 79 (1939); Bankers Trust Co. v. Palmer, 109 F. (2d) 136 (C. C. A. 2d, 1940); Warren v. Palmer, 60 Sup. Ct. 865 (1940).

There are several other New Haven cases in which appeals have been taken to the Circuit Court of Appeals, 2d Circuit, which, so far as can be told, are still pending.

${ }^{10}$ See Continental Ill. Nat. Bk. \& Trust Co. v. Chicago, R. I. \& P. Ry., 294 U. S. 648, 685 (I935). 
Act. But both have failed to justify the hopes that speedy reorganizations would result-and, among other reasons, this is due to the absence of established judicial precedents.

Transferring to a special court, created for the purpose, of the jurisdiction now exercised by the district courts, together with a more appropriate separation of the functions of the Commission and the court, would be primarily a procedural reform to unify and systematize railroad reorganization law by judges with expert and special knowledge of the problems and with opportunity to devote their full time to the consideration of the issues presented in each case.

Moreover, if, as in both the Senate and House bills pending in the present Congress, a special court is established having a rank comparable with the circuit courts of appeals, with provision for direct appeal to the Supreme Court, final adjudications will be obtained much more satisfactorily, than is now possible with jurisdiction spread among some 85 district courts and to circuit courts of appeal. This will be true not only as to questions of statutory construction, but likewise as to the more elemental issues, most of which, ${ }^{41}$ after more than seven years, have not yet been conclusively determined in the courts. Because of the lack of uniformity of approach in the several district courts the existing system imposes an undue burden of uncertainty and expense upon the parties to a Section 77 proceeding.

Under the Judicial Code, the Supreme Court can, of course, be petitioned for a writ of certiorari in the event of conflict between two circuits on the same point. But the concept of a "conflict" is technical and not designed to promote the uniformity that is particularly desirable under a new code of reorganization procedure, such as Section 77 established in lieu of the equity precedents. Again, a direct conflict between circuits seldom occurs simultaneously. A large element of chance is involved. Meanwhile, established precedent in one circuit is of doubtful authority in another. In these circumstances, as federal practitioners are aware, appeals are frequently taken to the circuit court in the hope that a conflict will develop which will afford a ground for taking the çase to the Supreme Court for a settlement of the issue. However, since the court's jurisdiction is limited to the case in which certiorari is granted, it cannot grant relief to those who have lost out in other cases where the time for appeal has run. Thus, it is the last litigant who profits from the ill fortune of his predecessor in another circuit. ${ }^{42}$

The reasons for the long delays in Section 77 cases are discussed elsewhere in this issue in detail. ${ }^{43}$ Regardless of other causes, there can be no question that the Interstate Commerce Commission has been seriously hampered by the lack of established judicial precedents systematizing the law under Section 77. It was not until 1938, more than five years after the passage of the original Act, that a district court

42 E.g., the conclusiveness of the 1 . C. C.'s determination of value.

${ }^{40}$ See Hankin, The Logan Bill (1938) 27 Kr. L. J., 1, 24. The Logan Bill, S. 3676, 75th Cong, 3d Sess. (1938), discussed in this article provided for a special court to hear appeals from various federal commissions. It is to be distinguished from the Logan Bill, S. 915, 76th Cong., ist Sess., passed by the Senate July $18,1939$.

"See Dembitz, supra note I, at 407. 
decision was obtained on a plan, stating that the rule of the Boyd case applied to proceedings under Section $77 .^{44}$ So vigorously did debtor interests deny the applicability of this rule to Section 77 that the whole Commission listened to argument on the question for two entire days in November, 1937-some four and a half years after the statute's enactment. 45

It must be realized that the Commission, by virtue of its being an administrative agency, is not well equipped to decide questions of this sort. Of the eleven Commissioners, taxed to capacity by their multitudinous other duties involving transportation, only four, according to testimony before the House Judiciary Committee, were ever practising lawyers. ${ }^{40}$ While the Commission has expedited its consideration of cases and, with the increased skill of its staff in such matters, the quality of its reports has improved, the bulk of these on reorganization plans has been issued since the introduction in Congress of bills for the establishment of a special railroad reorganization court.

\section{Some of the Arguments against a Spectal Court Examtned}

Editorial limitations prevent an extended discussion of the objections which have been urged to the creation of a special railroad reorganization court. Some will ke briefly noticed:

(I) It is wrong to create a court for a specialized purpose. This argument does not even appear to have the precedent of our Anglo-Saxon institutions. The establishment of new courts to adjudicate specialized classes of controversies has been 2 frequent occurrence. From time to time new courts have been created to deal with new problems, or problems which required different treatment from the usual run of cases that come before courts of general jurisdiction. Referring to English legal history, a recent writer has observed:48

\footnotetext{
at Memorandum opinion of Judge Barrett, Savannah \& Atlantic R. R. Reorg, Feb. 5, 1938.

"s The issue was presented in both the Spokane International and the Western Pacific reorganizations, Nov. 16-17, 1937.

"Hearing before the Special Bankruptoy Subcommittee of the House Committee on the Iudiciary on H. R. 10387, 75th Cong., 3d Sess. (1938) 83-84.

"See Hankin, supra note 42, at 6: "From the earliest days of English history to the present, new courts with new judicial procedures have sprung into being, to take care of the constant growth and changes in the law," referring to I Hordswortz, History or ENGLIss Law (3d ed. 1922).

The earliest, perhaps, of the English courts were the communal courts, consisting of the sheriff' and the coroners' courts. A second important group of local courts, established to meet specialized needs, were the franchise courts, divided by Holdsworth into five principal classes: (I) special courts for the ropal forests, which became obsolete with the repeal of the forest laws; (2) landowners' courts, some of which were merged with the High Courts of Justice under the Judicature Act of 1873; (3) Borough Courts, still recognized in the Municipal Corposations Act of 1835; (4) Courts of the Stanneries, maintained by mining interests and surviving to some extent to as recent a date; and (5) courts of the universities which retained criminal jurisdiction until 1879. A third great group of courts, once powrerful, included the feudal and manorial courts which became obsolete in the 18th century.

Other examples of specialized courts were (a) the Maritime Courts which adjudicated not ooly maritime questions but also actions for or against foreigners, their jurisdiction being gradually assumed by the Courts of Admiralty; (b) the Courts of the Fairs and Boroughs, dealing chiefly with the law of domestic trade; and (c) the Court of the Staple which concerned itself with the law of foreign trade. The last great type of special tribunal was the ecclesiastical courts, though mention should be made of the Court of the Constable and Marshal, superseded after 1689 by courts martial.
} 
In some instances, the new tribunals served their purpose, the special problems disappeared, and the courts were abolished. At other times, the new problems became crystal. lized into definite rules of law which could be as easily administered by the courts of general jurisdiction, with which the special courts became consolidated.

Though this country is younger than England, and consequently has a briefer legal history, the constitutional power of Congress to establish such inferior federal courts as may from time to time be required to meet new needs is beyond question ${ }^{40}$ -one of the many examples of the amazing foresight and wisdom of the framers of the Federal Constitution. Nor, has Congress heretofore not availed itself of its privilege under the Constitution. The Customs Court is an established part of our federal judicial system. ${ }^{49}$ In some of the states, surrogates' courts, domestic relations courts, juvenile courts, and the like are familiar examples of a similar development of special tribunals for special purposes.

(2) It is wrong to create a special court to meet the problem of a particular industry. This is a variation of the preceding argument. But for more than fifty years Congress has dealt with the railroads as a particular problem. From the passage of the Interstate Commerce Act in 1887 to date the regulation of railroads has been entrusted to an administrative tribunal, specially created for the purpose. That 2 railroad reorganization involves different questions than other corporate reorganizations was recognized by Congress in 1933 and again 1935, in the enactment and revision of Section 77 of the Bankruptcy Act.

(3) The creation of a special court is too great a step towards "centralization" of power. This argument overlooks the power over railroad reorganizations that Congress has already centralized in the Interstate Commerce Commission. It overlooks, also, the little-realized centralization of judicial power in railroad reorganizations, without the attendant benefits of a tribunal specially created to handle railroad reorganizations. Though, under Section 77 , original jurisdiction is conferred on some 85 federal district ccurts, three judges, two sitting in St. Louis, exercise jurisdiction over more than half the mileage involved in proceedings under the Act. ${ }^{\text {Do }}$ These three judges are charged with the custody of railroads which spread from Pensacola and the Mexican border on the south, to the Canadian border on the north, and to the Pacific Coast. Questions that arise under Section 77 relate, for the most part, to the Bankruptcy Act, or to the Interstate Commerce Act-both subjects of federal . law. There is no valid reason why a qualified special court cannot pass on these questions with as great a degree of competence, and, in addition, have as keen an appreciation of local conditions and the needs of the shipping and traveling public in a particular community as one of the three district judges in question. ${ }^{32}$

"U. S. Consr., ART. III, 5x, vesting the judicial power "in one supreme court, and in such inferior Courts as the Congress may from time to time ordain and establish."

"Established in 1922 to deal with the application of the tariff laws. Mention should also be made of the Court of Claims established in 1855 , though the latter is not a constitutional courc. Reasons why the United States Commerce Court, established in 1910 , was abolished in $19 \times 3$ are discussed in House Hearings, Pt. 2, p. 102.

${ }^{\circ 0}$ House Hearings, PL. 2, p. 20.

${ }^{82}$ Moreover, under S. $1869, \$ 4$ (b), provision is made for decentralizing ordinary matters of administration by imposing on the appropriate federal district court, subject to review by the special court, euch 
(4) A special court could not handle the volume of work which would be imposed upon it. This, obviously, is not an argument against the merits of the proposal to create a special court. That a court which specializes in a particular class of controversies is able to dispose of more cases than a court of general jurisdiction, having, in addition the adjudication of a great mass of other cases, is a demonstrated fact. ${ }^{52}$ Furthermore, the fact that such a court can devote its whole time to a particular task is not the only benefit to be derived. For one thing, where the cases that come before a court are of a particular class, they can be disposed of with less effort. Again, a special court would have all the cases before it and, therefore, would soon come to recognize sparring for position on the part of interests that still hope for a restoration of earnings above the r935-r937 level.53 Because the opportunities for dual litigation, already referred to, would be reduced by establishing a special court, the demands upon it should likewise be less time-consuming. Certainly, a special court would be in a position to handle its work more expeditiously than are the federal district courts and the Interstate Commerce Commission which are each charged with a myriad of other duties.

(5) To establish a special court now, with so many cases before the Interstate Commerce Commission either completed or nearing completion, would be "swapping horses" in the middle of the stream. There would be considerable force to this argument were the special court more likely than the district courts to upset what has already been done by the Interstate Commerce Commission. ${ }^{54}$ Under the House bill no swapping of horses was involved so far as the Commission was concerned, since the main effect of that bill was merely to substitute a special court for the district courts and to eliminate the possibility of the shuttling of plans by permitting the special court to modify in a proper case the plan certified to it by the Commission..$^{55}$ Under the Senate bill, ${ }^{\text {se }}$ the possibility of any serious wastage of the

of the duties and power of the latter "in connection with the actual operations of the properties in the course of the receivership, trusteeship or reorganization of the railroad corporations involved" as to the special court "may be considered necessary and proper for prompt and expeditious handling."

"s Thus in one year, 1936, the Customs Court was able to dispose of some 71,492 cases. In the same year all of the federal district courts disposed of 141,167 cases. REP. ATr'Y. GEN. (1936) 117, 157. In one year, 1936, the Court of Claims disposed of 473 cases. In the fiscal year, 1936, the total number of cases disposed of by the various circuit courts of appeals (including the Court of Appeals for the District of Columbia), sitting in panels of three, was 3,526, an average of 235 cases per panel. Hankin, supra note 42, 2t I0.

"The handicap under which the average cour labors in a railroad reorganization case was recognized by the late Chief Justice Taft, when Circuit Judge, in an address before the Ameriean Bar Association: "Cours usually have so much to attend to that they do not and cannot investigate the weight or validity of reasons for delay in causes when not brought to their attention by complaint of some of the parties." 2aft, Recent Criticism of the Federal Judiciary (1895) 18 A. B. A. Rep. 237, 263.

"From the present prospects most of the plans involving Class I railroads will be contested in the courts. As of the present writing, objections have been filed to the Commission's plans in the Western Pacific, Chicago \& North Western, Missouri Pacific, and Denver \& Rio Grande Western cases.

BE. R. 2531, 76th Cong., Ist Sess. (1939) tit. III.

st $\mathrm{S}$. 1869 . Under this bill the judicial process in bankruptcy proceedings would continue to be "brigaded with the administrative process of the Commission," since the Commission would continue 
work already done by the Commission in pending cases might readily have been prevented by amendment, such as was suggested in the hearings. .57

(5) The creation of a special court would involve an unconstitutional mingling of judicial and administrative functions. The witness at the hearings before the House Subcommittee who advanced this argument, urged that a special court, such as was provided for in S. 1869 , would be unconstitutional, because, in certain circumstances, such court could propose a plan. ${ }^{58} \mathrm{He}$ overlooked that, in a railroad reorganization case, the crucial judicial question is the fairness of the plan, and that, under the existing provisions of Section $77^{50}$ if the district court disapproves the Commission's plan, it must, in effect, set forth the requirements of what in its opinion is a fair and equitable plan since it must write an opinion setting forth its objections to the Commission's plan. It is not fair to assume that the members of a special court, appointed by the President with the advice and consent of the Senate, will disregard constitutional inhibitions.

When analyzed, the issues which underlie the proposal for a special court are broad ones. First, are we to have sound railroad reorganizations? Obviously, we shall not unless the court handling the case is in a position to bring an informed judgment to its adjudication. Secondly, can railroad credit be restored in time to cure what constitutes a dangerous gangrene in our whole economy? It can be rehabilitated in a substantial degree by putting the railroad house in order and taking out of the courts those roads which are ready for reorganization. To accomplish this expeditiously, we need a reformed reorganization procedure, including the creation of a special railroad reorganization court.

In many respects, the continuance of the railroads, over the longer term, under private ownership and operation, depends upon a solution of their financial diffculties. At the present time access to the private capital market is denied to all but the strongest roads..$^{60}$ The involvement of so many roads in reorganization proceedings, without visible prospects of an early termination, is a depressing infuence on the railroad bond market. The ability of other roads to finance themselves awaits not only an improvement of their earning power but a simplification of their capital structures. For roads which can no longer qualify for loans from the Reconstruction Finance Corporation, there is no likely alternative except a reduction of fixed charges, unless Congress amends the present Reconstruction Finance Corporation Act. ${ }^{61}$

to have the important duties of determining the maximum capitalization of the reorganized company, maximum fixed charges, etc.

${ }^{87}$ See the author's statement before the House Subcommittee and the amendments proposed by the R. F. C., House Hearings, Pt. 1, pp. 529, 922.

${ }^{80} \mathrm{Mr}$. Leslie Sraven in House Hearings, Pt. 2, pp. 243-245. $\quad{ }^{30} \mathrm{Sec} 377(c)$.

${ }^{\circ}$ Exclusive of terminal companies, the bonds of which were guaranteed, only two railroads-the Chesapeake \& Ohio and the Wheeling \& Lake Erie, both roads of high credit rating-sold publicly offered issues of railroad bonds during the calendar years 1938 and 1939.

${ }^{-2}$ Under $\$ 5$ of the Reconstruction Finance Corporation Act, as ancnded, not only must a railroad applying for a loan from R. F. C. offer "full and adequate security," but likewise the I. C. C. must find 
With an industry of the size and importance of the railroads, with the intimate relationship between this industry and the entire economic structure of the country and the national defense, and with well-nigh universal agreement as to the national interest concerned, it is hard to see why the opposition of specialized and conflicting interests should be allowed to block steps aimed to enable the railroads to put their own house in order so that they can meet the necessities of the new transportation age in which we live.

that the road can reasonably be expected to meet its fixed charges, "without a reduction -thereof through judicial rcorganization." This finding is required in all cases except in case of "Ioans made for the maintenance of, or purchase of equipment for." If the R. F. C. purchases railroad bonds, "the price to be paid" must be approved by the 1. C. C. and the latter must certify as to carnings. 